\title{
Optimization of hydrolysis conditions for xylans and straw hydrolysates by HPLC analysis
}

\author{
Alexander Beckendorff ${ }^{1} \cdot$ Anne Lamp ${ }^{1} \cdot$ Martin Kaltschmitt $^{1}$ \\ Received: 4 December 2020 / Revised: 23 February 2021 / Accepted: 5 March 2021 / Published online: 20 March 2021 \\ (C) The Author(s) 2021
}

\begin{abstract}
Oligosaccharide analysis is commonly done by acid hydrolysis and following HPLC analysis. A major problem is the incomplete hydrolysis of oligosaccharides and disaccharides and the increasing formation of volatile furfural from pentose monomers and hydroxymethylfurfural (HMF) from hexose monomers. This paper optimizes the conditions of hydrolysis approaches and proposes a method for oligosaccharide quantification. The optimal condition for hydrolysis of model xylan from corn cob was found to be for $100{ }^{\circ} \mathrm{C}$ hydrolysis temperature, $120 \mathrm{~min}$ hydrolysis time, and $2 \mathrm{wt} \%$ sulfuric acid concentration. Under these conditions, the total free and bound xylose yield was $77.4 \%$ and hemicellulose conversion $87.4 \%$ respectively; no degradation products were found. The optimal conditions for hydrolysis of model xylan from beech wood were found to be for $120{ }^{\circ} \mathrm{C}$ hydrolysis temperature, $120 \mathrm{~min}$ hydrolysis time, and $2 \mathrm{wt} \%$ sulfuric acid concentration. Under these conditions, the total free and bound xylose yield was $65.1 \%$ and hemicellulose conversion $70.5 \%$ respectively; no degradation products were found. For pentosan hydrolysate, conditions were further optimized $\left(110{ }^{\circ} \mathrm{C}, 60 \mathrm{~min}, 2 \mathrm{wt} \% \mathrm{H}_{2} \mathrm{SO}_{4}\right)$. Standard addition of xylan from the corn cob for hydrolysation showed similar conversion rates $(<2 \%$ deviation); no matrix effects were detected.
\end{abstract}

Keywords Pentosans $\cdot$ Oligosaccharides $\cdot$ Quantification $\cdot$ HPLC $\cdot$ Xylose

\section{Introduction}

Carbohydrates represent a major portion of biomass samples and consist mainly of polysaccharides constructed primarily of glucose, xylose, arabinose, galactose, and mannose monomeric subunits. In general, carbohydrates with a degree of polymerization (DP) lower than 10 are called oligosaccharides, while polysaccharides show a DP above 10 [1].

During hydrothermal pretreatment of lignocellulosic biomass, a certain share of these polysaccharides is partly hydrolyzed to water-soluble oligomers and monomers. They are

Alexander Beckendorff

alexander.beckendorff@tuhh.de

Anne Lamp

anne.lamp@tuhh.de

Martin Kaltschmitt

kaltschmitt@tuhh.de

1 Institute of Environmental Technology and Energy Economics, Hamburg University of Technology (TUHH), Eißendorfer Straße 40, D-21073 Hamburg, Germany hereafter referred to as sugar monomers being mainly xylose and glucose [2]. HPLC with refractive index detection enables the quantification of these soluble sugars as well as the subsequent carbohydrate degradation products (e.g., HMF and furfural). If the sugars are present in an oligomeric structure, an additional hydrolysis to separate the monomeric units is required.

Important parameters affecting the hydrolysis of pentose oligomers are temperature, time, and acid concentration. The challenge is that a complete hydrolysis of oligomeric structures is aimed for, while the further degradation of the released saccharides should be avoided as much as possible. This is true because typically, the combination of extreme temperatures $\left(140^{\circ} \mathrm{C}\right)$ and long treatment time periods $(>3 \mathrm{~h})$ during hemicellulose and cellulose hydrolysis leads to the degradation of the released monomeric sugars into insoluble humin. This final degradation product is typically challenging to quantify [3].

Most studies investigating lignocellulose pretreatment follow the NREL method for the quantification of overall C5 sugar content [4]. The problem with this measurement method is that the optimum conditions for the recovery of C5 and C6 sugars are not the same, since cellulose requires temperatures 
Fig. 1 Partial chemical structure of an arabinoxylan pentosan a linear $\beta$-1.4-D-xylopyranosyl backbone structure linked with randomly attached side chains of $\alpha$-L-arabinofuranosyl at 2 and/or 3 position of the xylose chain [8]

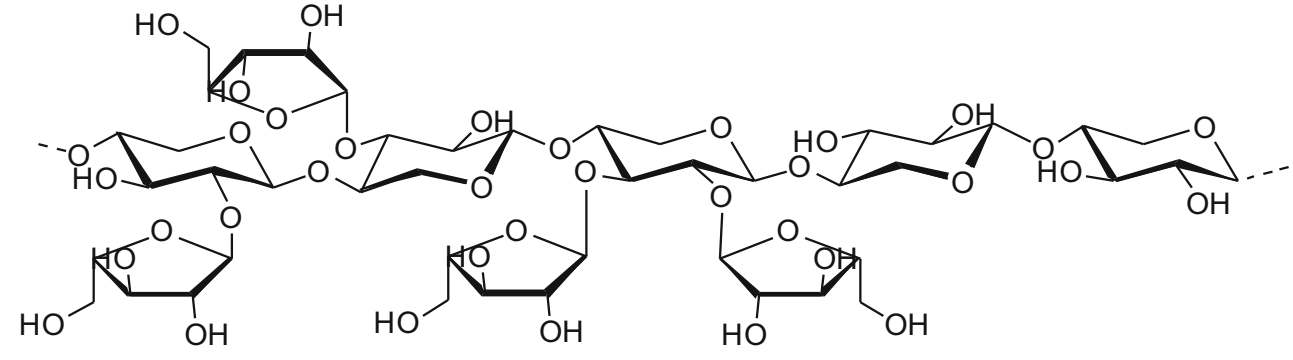

higher than hemicellulose for a complete hydrolysis. Thus, these higher temperature level results in more frequent degradation of C5 sugars. Furthermore, the interaction effects of temperature and time during the hydrolysis of $\mathrm{C} 5$ and $\mathrm{C} 6$ oligomers are hardly fully understood.

In this work, two model xylans as well as an unknown C5 sample from liquid hot water hydrolysis are investigated and optimized in terms of temperature, time, and acid concentration using HPLC-RI detection and response surface methodology with Box-Behnken design. The aim is to find the optimal hydrolysis conditions for a maximum recovery of total (free and bound) xylose and glucose from the different oligomers, respectively. The additional inclusion of the degradation products HMF and furfural enables full monomeric recovery. Furthermore, this paper aims to adjust the calculation of the total xylose recovery by adding a correction factor considering monomeric losses and degrading product formation, following the method of Lamp et al. [5]. Solid-phase analysis of products was not considered.

\subsection{Pentosan structure}

Pentosans are polymeric anhydrides of pentoses, mainly consisting of xylans, with an occurrence in wooden biomass [6]. Xylan itself is synthesized by enzymes in the Golgi apparatus. Xylan synthesis thus requires the coordinated action and regulation of these enzymes as well as others that synthesize and transport substrates [7].
Pentosans from plant tissues and cereals are carbohydrates consisting of a linear $\beta$-1.4-D-xylopyranosyl backbone structure linked with side chains of $\alpha$-L-arabinofuranosyl at 2 and/ or 3 position of the xylose chain (Fig. 1) [8].

Lignocellulosic biomass mainly consists of lignin, cellulose, and hemicellulose. During acid-catalyzed thermal hydrolysis, polymeric saccharides are depolymerized into their monomeric forms. Figure 2 illustrates the conversion paths of lignocellulosic biomass from polymeric structure via monomeric sugars - glucose from cellulose and hemicellulose, $x y-$ lose from hemicellulose - towards 5-hydroxymethylfurfural from glucose and furfural from xylose. A prominent example of the conversion process is the acid-catalyzed thermal hydrolysis of the polymeric saccharides, releasing C5 and C6 saccharides. For example, harsh reaction conditions like temperatures above $140{ }^{\circ} \mathrm{C}$ lead to the formation of undesired humin byproducts [9].

The formation of aqueous xylose monomers from solid xylan is described in a simple model of reversible reactions. However, the decomposition of xylan to xylose is in fact a multistep process. The xylan chain is first decomposed to xylo-oligosaccharides, then decomposition proceeds to xylose monomer, followed by the further decomposition into furfural [10].

\subsection{Pentosan quantification methods}

Quantitative pentosan analysis is mainly done by the quantification of the sugar monomers within the pentosan molecules
Fig. 2 Conversion paths of cellulose and hemicellulose during acid hydrolysis [9]

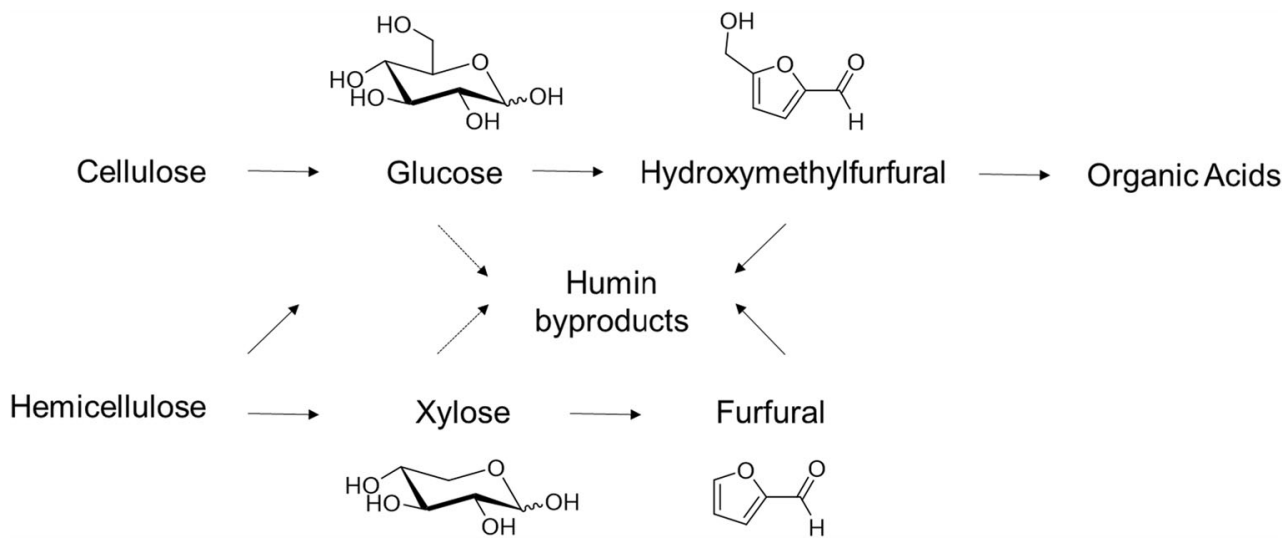


Table 1 Calculation of hydrolysis outcomes

\begin{tabular}{|c|c|c|}
\hline Definition (\%) & Calculation & Equation \\
\hline Xylose yield & $\frac{\text { Xylose }(\mathrm{mol}) 0.88}{\text { Hemicellulose }(\mathrm{mol})} 100$ & (2) \\
\hline Arabinose yield & $\frac{\text { Arabinose }(\mathrm{mol}) 0.88}{\text { Hemicellulose }(\mathrm{mol})} 100$ & (3) \\
\hline Glucose yield & $\frac{\text { Glucose }(\mathrm{mol}) 0.9}{\text { Cellulose }(\mathrm{mol})} 100$ & (4) \\
\hline Furfural yield & $\frac{\text { Furfural }(\mathrm{mol}) 1.375}{\text { Hemicellulose }(\mathrm{mol})} 100$ & (5) \\
\hline HMF yield & $\frac{\mathrm{HMF}(\mathrm{mol}) 1.286}{\text { Cellulose (mol) }} 100$ & (6) \\
\hline $\begin{array}{l}\text { Hemicellulose } \\
\text { conversion }\end{array}$ & $\frac{\text { Xylose (mol) } 0.88+\text { Arabinose (mol) } 0.88+\text { Furfural (mol) } 1.375}{\text { Hemicellulose (mol) }} 100$ & (7) \\
\hline Cellulose conversion & $\frac{\text { Glucose }(\mathrm{mol}) 0.9+\mathrm{HMF}(\mathrm{mol}) 1.286}{\text { Cellulose }(\mathrm{mol})} 100$ & (8) \\
\hline Furfural selectivity & 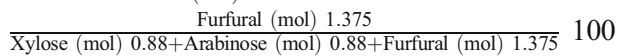 & (9) \\
\hline HMF selectivity & 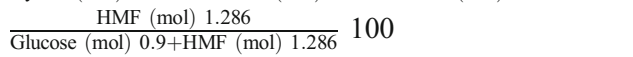 & (10) \\
\hline \multicolumn{3}{|l|}{ Correction factor } \\
\hline 0.88 & $M_{\text {xylan }} / M_{\text {xylose }}$ & (11) \\
\hline 0.9 & $M_{\text {glucan }} / M_{\text {glucose }}$ & (12) \\
\hline 1.375 & $M_{\text {xylan }} / M_{\text {furfural }}$ & (13) \\
\hline 1.286 & $M_{\text {glucan }} / M_{\mathrm{HMF}}$ & (14) \\
\hline Combined severity factor & $\log \mathrm{CSF}=\log t+\log \left(e^{\left(\frac{T-100}{14.75}\right)}\right)$ & (15) \\
\hline
\end{tabular}

Table 2 Experimental plan

\begin{tabular}{|c|c|c|c|c|c|c|c|c|c|}
\hline & Temp $\left(\mathrm{C}^{\circ}\right)$ & Acid (wt\%) & Time (min) & Temp $\left(\mathrm{C}^{\circ}\right)$ & Acid (wt $\%)$ & Time (min) & Temp $\left(\mathrm{C}^{\circ}\right)$ & Acid (wt $\%)$ & Time (min) \\
\hline Run & \multicolumn{3}{|c|}{ Corn cob xylan } & \multicolumn{3}{|c|}{ Beech wood xylan } & \multicolumn{3}{|c|}{ C5 straw hydrolysate } \\
\hline 1 & 100 & 4 & 180 & 100 & 4 & 180 & 100 & 4 & 180 \\
\hline 2 & 100 & 2 & 120 & 100 & 2 & 120 & 100 & 2 & 120 \\
\hline 3 & 100 & 6 & 120 & 100 & 6 & 120 & 100 & 6 & 120 \\
\hline 4 & 100 & 4 & 60 & 100 & 4 & 60 & 100 & 4 & 60 \\
\hline 5 & 120 & 4 & 120 & 120 & 4 & 120 & 110 & 4 & 120 \\
\hline 6 & 120 & 4 & 120 & 120 & 4 & 120 & 110 & 4 & 120 \\
\hline 7 & 120 & 4 & 120 & 120 & 4 & 120 & 110 & 4 & 120 \\
\hline 8 & 120 & 6 & 180 & 120 & 6 & 180 & 110 & 6 & 180 \\
\hline 9 & 120 & 2 & 180 & 120 & 2 & 180 & 110 & 2 & 180 \\
\hline 10 & 120 & 4 & 120 & 120 & 4 & 120 & 110 & 4 & 120 \\
\hline 11 & 120 & 4 & 120 & 120 & 4 & 120 & 110 & 4 & 120 \\
\hline 12 & 120 & 6 & 60 & 120 & 6 & 60 & 110 & 6 & 60 \\
\hline 13 & 120 & 2 & 60 & 120 & 2 & 60 & 110 & 2 & 60 \\
\hline 14 & 140 & 4 & 60 & 140 & 4 & 60 & 120 & 4 & 60 \\
\hline 15 & 140 & 2 & 120 & 140 & 2 & 120 & 120 & 2 & 120 \\
\hline 16 & 140 & 6 & 120 & 140 & 6 & 120 & 120 & 6 & 120 \\
\hline 17 & 140 & 4 & 180 & 140 & 4 & 180 & 120 & 4 & 180 \\
\hline 18 & 100 & 6 & 60 & & & & & & \\
\hline 19 & 100 & 6 & 60 & & & & & & \\
\hline 20 & 100 & 6 & 120 & & & & & & \\
\hline 21 & 100 & 6 & 120 & & & & & & \\
\hline 22 & 100 & 6 & 180 & & & & & & \\
\hline 23 & 100 & 6 & 180 & & & & & & \\
\hline 24 & 100 & 4 & 180 & & & & & & \\
\hline
\end{tabular}


Fig. 3 Design of experiments 2Dresponse surface plot of released xylose from corn cob xylan hydrolysis versus temperature (a) and time (b) at $2 \mathrm{wt} \%$ (top left), $4 \mathrm{wt} \%$ (top right), $6 \%$ (bottom left) acid concentration
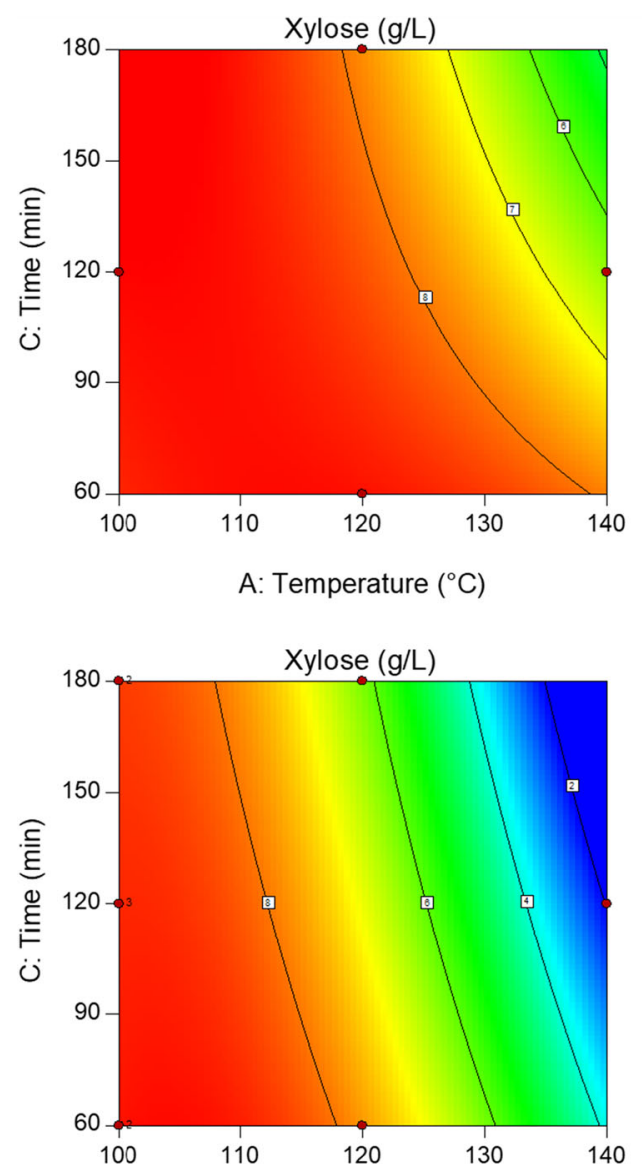

A: Temperature $\left({ }^{\circ} \mathrm{C}\right)$

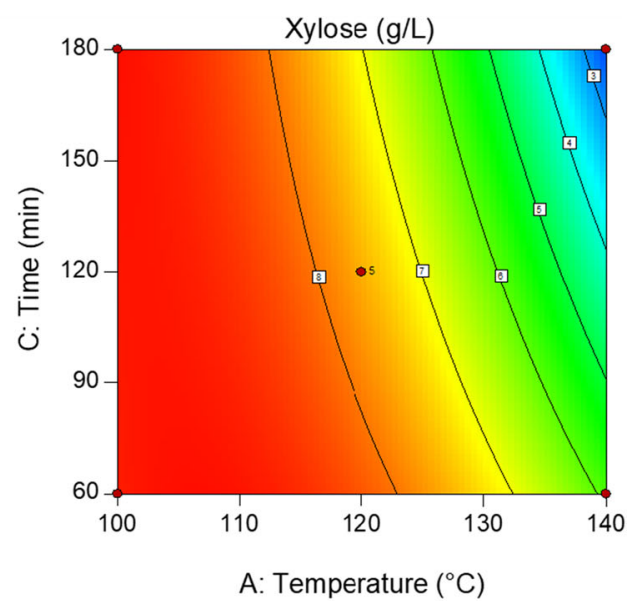

\subsection{3̄23 Actual Factor B: Acid concentration}

2.12658 and a subsequent recalculation step [11]. Generally, pentosan analysis includes the following fundamental steps:

- Extraction of pentosans from sample matrix,

- Purification of pentosan extract,

- Hydrolysis of pentosan chains,

- Determination and quantification of the released monomeric sugars xylose and arabinose for pentosans, and

- Calculation of the original pentosan amount.
A widely spread procedure for sugar determination was established by Sluiter et al. [12], covering sugar, byproducts, and degradation products in liquid fraction process. The subsequent calculation of oligosaccharide concentration after acid hydrolysis is based on the method described by Huynh et al. [13] and was extended by Verspreet et al. [14] (Eq. (1)).

$S(\%)=\frac{M_{s} V_{e}\left(S_{b}-S_{a}-S_{x}\right)}{m_{s}}$
Fig. 4 Combined severity factors of temperature and time of released xylose yield form corn cob xylan (CCX) hydrolysis, displaying 2 to $6 \mathrm{wt} \%$ acid concentration

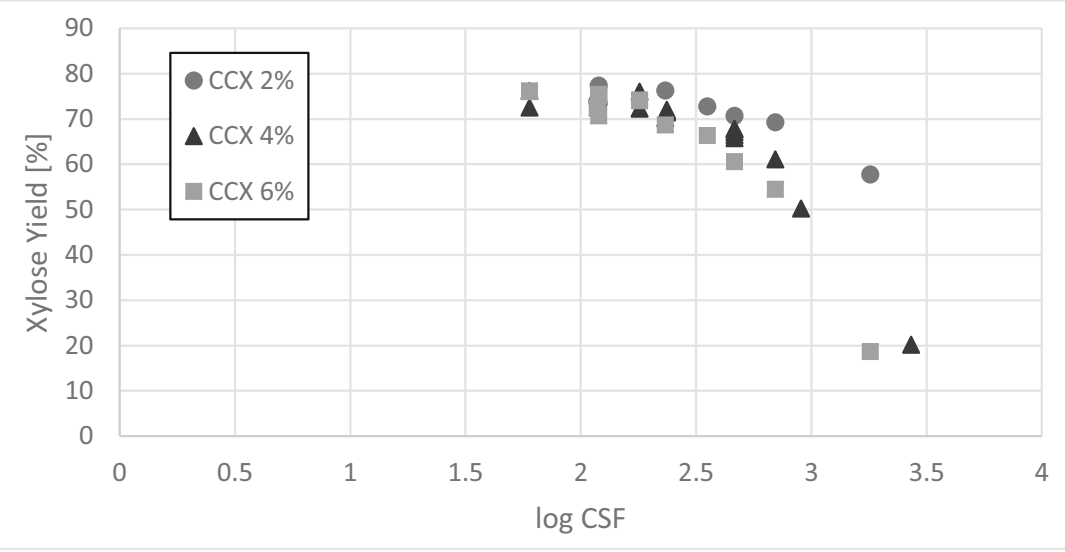


Fig. 5 Design of experiments 2Dresponse surface plot of released xylose from beech wood xylan hydrolysis versus temperature (a) and time (b) at $2 \mathrm{wt} \%$ (top left), $4 \mathrm{wt} \%$ (top right), and 6 wt $\%$ (bottom left) acid concentration
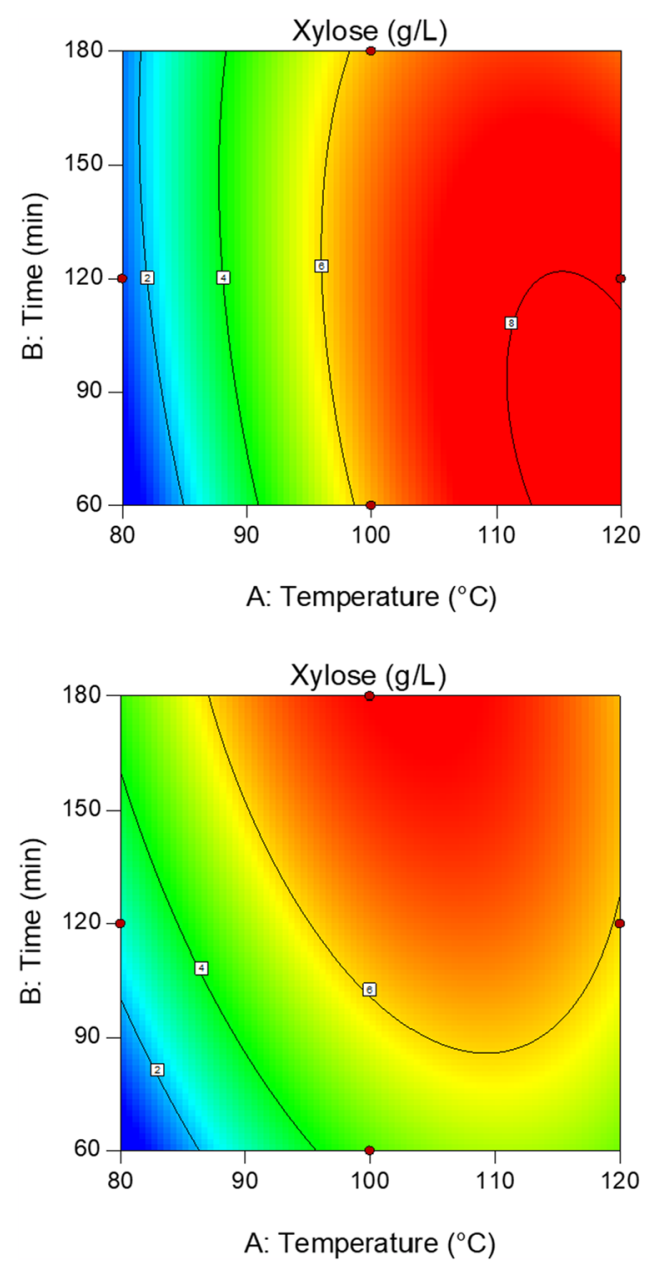

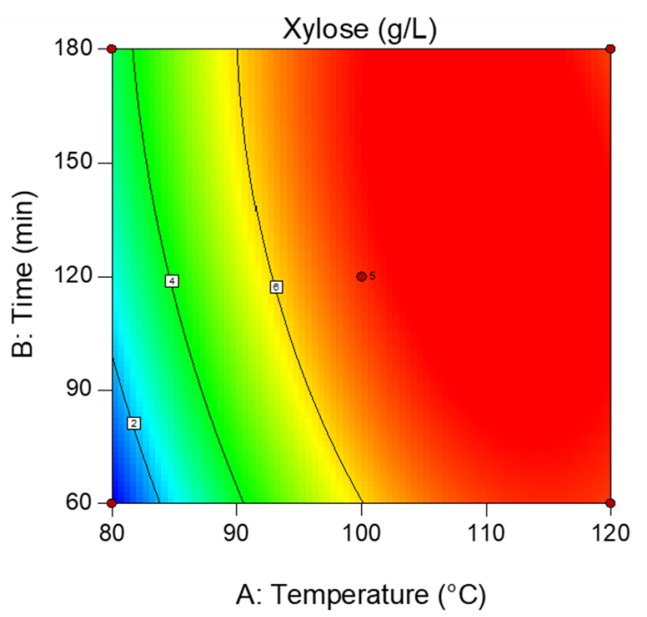

\subsection{7̄14 Actual Factor B: Acid concentration 0.662061}

Equation (1) describes the concentration of the monomeric $S_{x}$ saccharides released from the oligomeric structure, where

$M_{s}(\mathrm{~g} / \mathrm{mol}) \quad$ is the molecular weight of the saccharide monomer,

$V_{e}(\mathrm{~mL}) \quad$ is the volume of the extract,

$m_{s}(\mathrm{~g}) \quad$ is the sample mass,

$S_{a}$ and $S_{b} \quad$ are the saccharide monomer concentrations in $(\mathrm{g} / \mathrm{L}) \quad$ the non-hydrolyzed and the hydrolyzed sample, respectively, and
$S_{x} \quad$ is the concentration of disaccharides containing the searched monomer.
Fig. 6 Combined severity factors of temperature and time of released xylose yield form beech wood xylan (BWX) hydrolysis, displaying 2 to $6 \mathrm{wt} \%$ acid concentration
This calculation does not account for a monomer yield loss due to the formation of HMF and furfural during oligomer hydrolysis. An alternative method for pentosan quantification is the colorimetric UV/Vis detection after acidic hydrolysis [15].

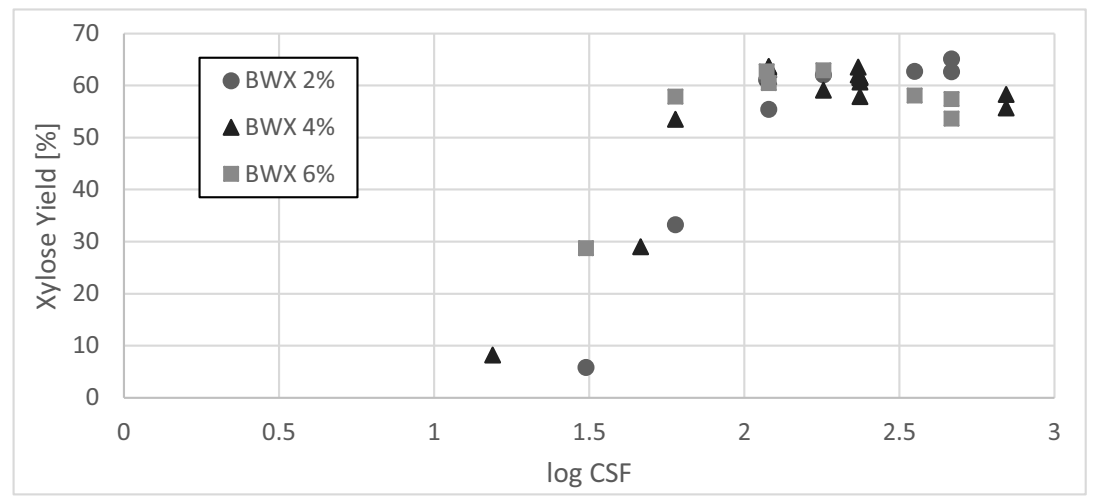


Fig. 7 Design of experiments 2Dresponse surface plot of released xylose from C5 hydrolysate hydrolysis versus temperature (a) and time (b) at $2 \mathrm{wt} \%$ (top left), $4 \mathrm{wt} \%$ (top right), and $6 \mathrm{wt} \%$ (bottom left) acid concentration
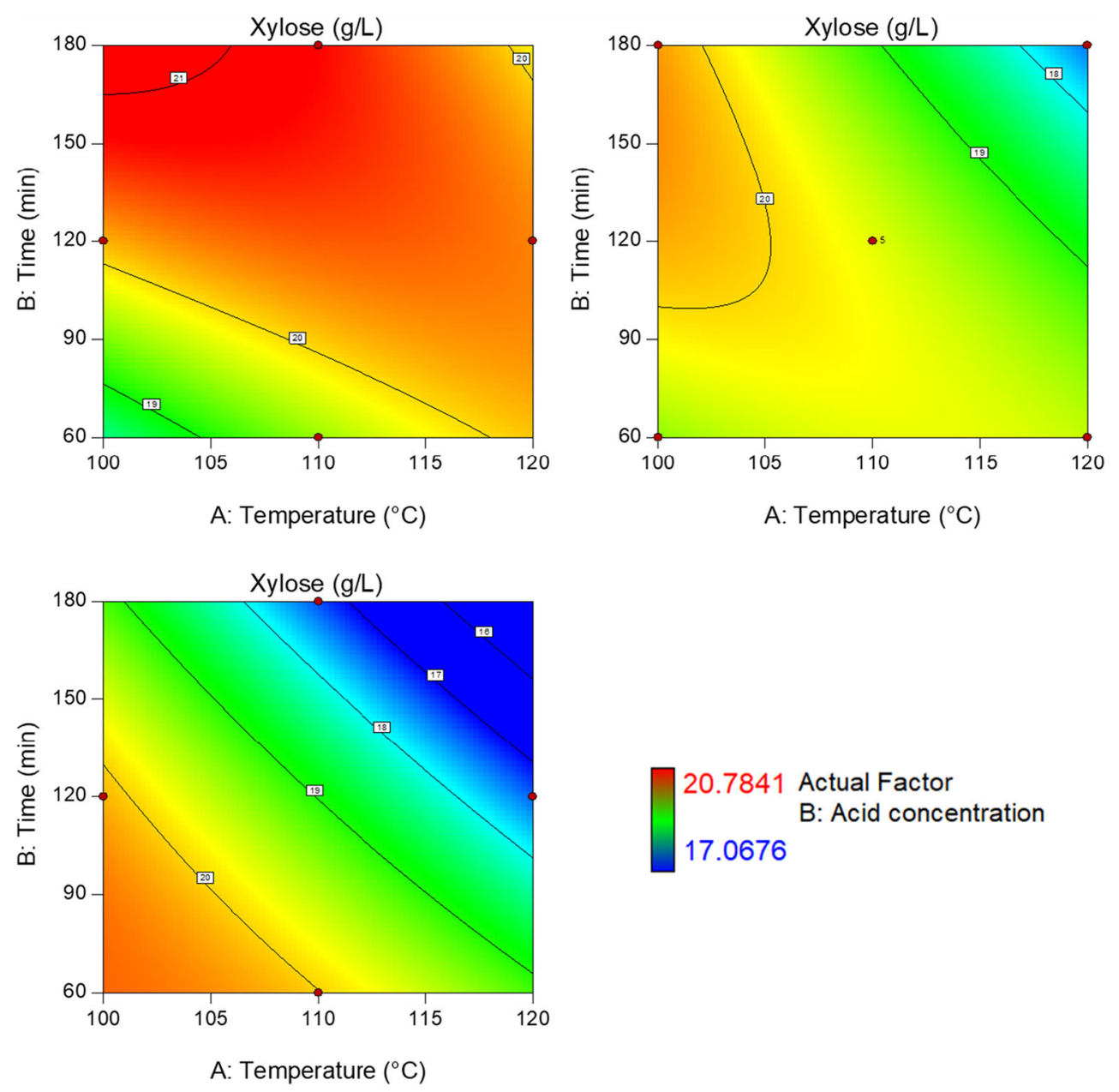

A: Temperature $\left({ }^{\circ} \mathrm{C}\right)$

\subsection{Actual Factor B: Acid concentration}

17.0676

\section{Experimental methods}

\subsection{Materials}

Monomeric and oligosaccharide standards were purchased from Carl Roth GmbH. Beech wood and corn cob xylans (132 $\mathrm{g} / \mathrm{mol}$ ) were provided with a $95 \%$ purity and used without further purification. Wheat straw extract from liquid hot water treatment (LHW) was used as an unknown sample material [16].

\subsection{Hydrolysis}

The optimization of the hydrolysis conditions has been executed in two steps. First, standard samples of beech wood xylan and corn cob xylan were investigated to find the optimal
Fig. 8 Combined severity factors of temperature and time of released xylose concentration form C5 hydrolysate hydrolysis, displaying 2 to $6 \mathrm{wt} \%$ acid concentration

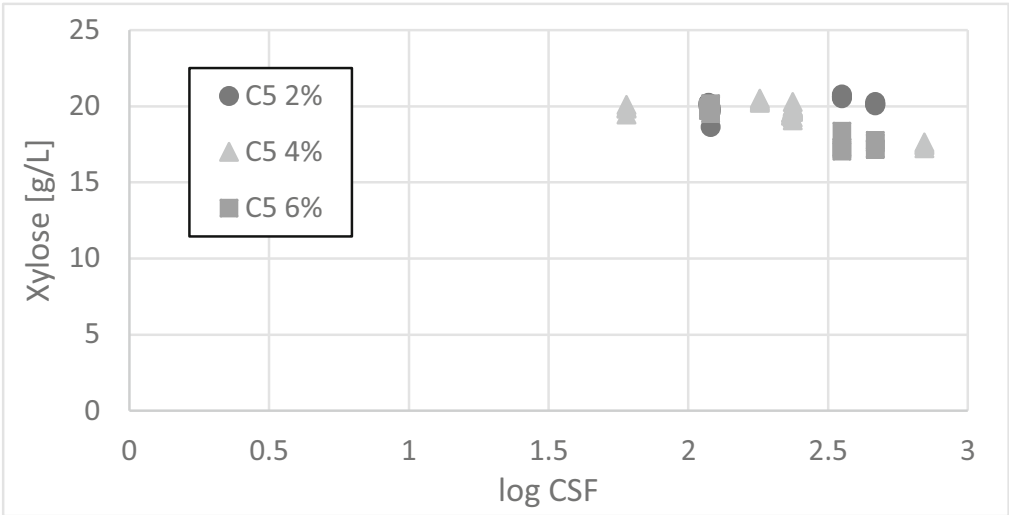


Fig. 9 Summed up hydrolysis results from combined corn cob xylan dilution row and $\mathrm{C} 5$ hydrolysate displaying the determined concentrations of released monomers; the hydrolysis was executed at 110 ${ }^{\circ} \mathrm{C}, 2 \mathrm{wt} \%$ sulfuric acid, and 60 min run time. With corn cob xylan solution (bottom bar, dark gray), C5 hydrolysate (top bar, light gray), and combined solution of both substrates (line)

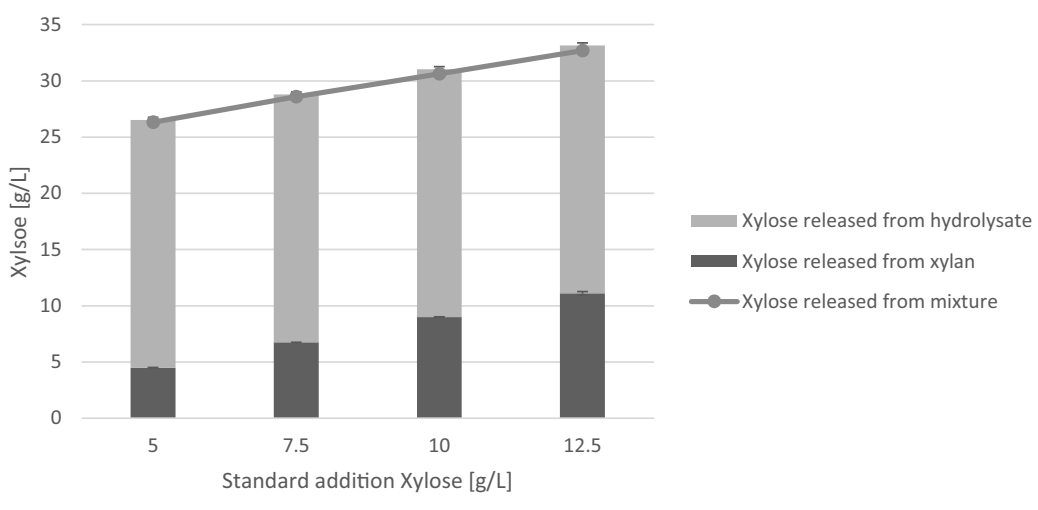

hydrolysis conditions for maximum total sugar recovery. Second, these conditions have been applied to an unknown sample of a liquid hot water pretreated wheat straw extract (see the "2.1. Materials" section).

- In case of the standard xylans, $2 \mathrm{~g}$ (66.6 mmol) was diluted in $200 \mathrm{~mL}$ demineralized water. For standard hydrolysis procedure, 175/350/525 $\mu \mathrm{L}(2,4,6 \mathrm{wt} \%)$ sulfuric acid $\left(\mathrm{H}_{2} \mathrm{SO}_{4} 72 \%\right)$ were added to the sample $(10 \mathrm{~mL})$ in a 10 -mL cuvette with screw cap. The cuvette was incubated at $80,100,110,120$, and $140{ }^{\circ} \mathrm{C}$ in a thermal reactor (TR420 thermal reactor from Merck) for 60, 120, and $180 \mathrm{~min}$. The temperature ranges from $80{ }^{\circ} \mathrm{C}$ as to determine the minimum temperature that enables hydrolysis of xylan structures, while at 140 ${ }^{\circ} \mathrm{C}$ humin byproducts are formed rapidly, hence inhibiting the aim of complete monomer release and recovery. Immediately after incubation, the cuvette was cooled in an ice water bath at $0{ }^{\circ} \mathrm{C}$ until room temperature was reached. The solution was transferred to a $10-\mathrm{mL}$ centrifuge tube and neutralized to $\mathrm{pH} 7$ by adding $\mathrm{CaCO}_{3}$. The samples were stored at $4{ }^{\circ} \mathrm{C}$ for $24 \mathrm{~h}$, then centrifuged $(15 \mathrm{~min}$, $4500 \mathrm{~min}^{-1}$ ), and the supernatants were stored for HPLC measurement. For the unknown sample (LHW-C5 hydrolysate), the same procedure has been executed in the range of 100 to $120{ }^{\circ} \mathrm{C}$ found to be the optimal range of hydrolysis parameters for xylans.

- For standard addition of xylan to hydrolysate, stem solutions were prepared. In case of corn cob xylan, 5.0, 7.5, 10.0 , and $12.5 \mathrm{~g}$ were diluted in $1000 \mathrm{~mL}$ demineralized water. An identical dilution row was prepared with the unknown hydrolysate from the wheat straw (LHW-C5 hydrolysate). Treatment of the samples followed the standard procedure in triplicates, at $110{ }^{\circ} \mathrm{C}, 2 \mathrm{wt} \%$ sulfuric acid and 60 and 90 min reaction time.

\subsection{HPLC analysis}

The amount of xylose and glucose as well as the degradation products - furfural and acetic acid from xylose, 5-hydroxymethylfurfural and formic acid from glucose-were measured by HPLC (Agilent Infinity II HPLC Series [5.3]). Sugar separation was achieved using a Biorad Aminex HPX-87P column with ionic form $\mathrm{H}^{+} / \mathrm{CO}_{3}{ }^{-}$deashing guard column and an Agilent Hi-Plex $\mathrm{H}^{+}$column. A total of $5 \mathrm{mmol}$ sulfuric acid was used as the mobile phase. Detection has been realized by a refraction index detector. The calibration process followed the adjusted method of NREL [12]. Standard solutions of glucose, xylose, arabinose, formic acid, acetic acid, 5-hydroxymethylfurfural, and furfural were prepared in the range between 0.024 and $24 \mathrm{mg} /$ $\mathrm{mL}$ (Table 3).

\subsection{Yields and conversions of saccharides and degradation products}

The yields of released xylose and arabinose from hemicellulosic xylans as well as the conversion of the aforementioned saccharides towards furfural were determined by the method of Chen et al. [17] and expanded by the addition of arabinose yield. Chen et al.'s pretreatment combines sulfuric acid and moderate temperatures by conventional heating, followed by microwave irradiation heating. The equations for monomer yields and polymer conversion calculations as well as degradation product selectivity, correction factors for saccharides, reaction products, and the combined severity factor are displayed in Table 1. The hemicellulose stands for the total percentage of xylose, arabinose, and furfural converted from hemicellulose; the cellulose conversion designates the total percentage of glucose and HMF converted from cellulose. 


\subsection{Box-Behnken experimental design}

The Box-Behnken design with response surface method was used to optimize the hydrolysis conditions to obtain the maximum amount of converted pentosan and xylose yield, achieving full monomeric recovery. Furthermore, interaction effects of the independent factors on the amount of total converted hemicellulose and xylose yield were studied. The independent variables were hydrolysis temperature $\left(80\right.$ to $140{ }^{\circ} \mathrm{C}$ ), hydrolysis time (60 to 180 $\mathrm{min}$ ), and acid amount (2 to $6 \mathrm{wt} \%$ ), which resulted in a three-factor three-level design. Statistical experiment planning was executed by using a commercially available software (Design Expert 9.0 [18]) with a central composite approach. The experimental plan is shown in Table 2 and consists of the abovementioned parameters. A total of at least 17 experimental runs were performed, and the actual predicted values of the response along with the experimental conditions are summarized in Tables 4, 5, $6,7,8$, and 9 .

\section{Results and discussion}

\subsection{Hydrolysis optimization of corn cob xylan}

Results Application of the abovementioned conditions on corn cob xylan illustrated in Fig. 3 shows the released xylose concentrations. Bright (red) colored areas show the highest released xylose concentrations, while decreasing concentrations and eventually the lowest concentration are show in darkened colors, dark (blue) respectively.

The highest amount of converted hemicellulose (97.0\%) was detected at $140{ }^{\circ} \mathrm{C}, 2 \mathrm{wt} \%$ sulfuric acid, and 120 -min reaction time. The highest amount of xylose $(77.4 \%)$ was obtained at $100^{\circ} \mathrm{C}, 2 \mathrm{wt} \%$ sulfuric acid, and 120-min reaction time. Lowest amounts of xylose were found at $140{ }^{\circ} \mathrm{C}, 6 \mathrm{wt} \%$ sulfuric acid, and 120 -min reaction time $(18.7 \%)$ and $140{ }^{\circ} \mathrm{C}, 4 \mathrm{wt} \%$ sulfuric acid, and 180-min reaction time (20.3\%) (Table 4). Correspondingly, the highest furfural concentrations were found (33.3 and 33.4\%). Disregarding the $<5 \%$ impurities of the starting material, the full conversion is achieved and the highest amount of detected xylose increases to $81.4 \%$.

The calculated combined severity factors (CSFs) for corn cob hydrolysis are displayed in Fig. 4. The maximum xylose yields were achieved in the severity range of 1.5 to $2.5 \mathrm{CSF}$. Increasing severity factors higher than $2.5 \mathrm{CSF}$ show a decline in xylose yields. The decrease of xylose yields at high CSFs indicates the degradation of xylose over time at high temperatures.

Discussion The results are indicating that higher temperatures and longer reaction times favor the conversion of hemicellulose to water-soluble products up to a maximum temperature and time; hereafter, humin formation is heavily favored [9]. The hemicellulose conversion is directly linked to temperature and time. Increased temperature provides more thermal effects (e.g., molecular collisions) resulting in more frequent cleavage of gylcosidic bonds between xylans. Catalyzing sulfuric acid provided highest conversion yields at $2 \mathrm{wt} \%$ addition. Temperatures above $100{ }^{\circ} \mathrm{C}$ favor the formation of furfural from xylose and arabinose over time. Hence, the maximum released xylose concentration results in incomplete hemicellulose conversion, while complete hemicellulose conversion lowers the xylose yield due to degradation. The amount of converted furfural can be corrected by the factor of Eq. (13). Compared to the method of Sluiter et al. [12] the optimized parameters $\left(100^{\circ} \mathrm{C}, 2 \mathrm{wt} \%\right.$ acid, 120 $\mathrm{min}$ ) provide higher released xylose concentrations from corn cob xylan $(+14 \%)$ by reducing the degradation towards furfural $(-22 \%)$ at similar hemicellulose conversion rates.

\subsection{Hydrolysis optimization of beech wood xylan}

Results Released xylose monomers from beech wood xylan are illustrated in Fig. 5. Following this graphic, the highest amount of converted hemicellulose $(74.2 \%)$ was detected at $120^{\circ} \mathrm{C}, 4 \mathrm{wt} \%$ sulfuric acid, and 180 -min reaction time. The highest amount of xylose $(65.1 \%)$ was obtained at $100^{\circ} \mathrm{C}$, $2 \mathrm{wt} \%$ sulfuric acid, and 120-min reaction time. The lowest amounts of released xylose have been measured at $80{ }^{\circ} \mathrm{C}$, $2 \mathrm{wt} \%$ sulfuric acid, and 120 -min time $(6.3 \%)$, as well as 80 ${ }^{\circ} \mathrm{C}, 4 \mathrm{wt} \%$, and $60 \mathrm{~min}(8.7 \%$ ) (Table 5). A yield of $\sim 30 \%$ released xylose was detected at $80{ }^{\circ} \mathrm{C}, 6 \mathrm{wt} \%$, and $120 \mathrm{~min}$ and $80^{\circ} \mathrm{C}, 4 \mathrm{wt} \%$, and $180 \mathrm{~min}$. Thus, the temperature of 80 ${ }^{\circ} \mathrm{C}$ does not provide a complete hydrolysis of xylan structures at the chosen period and acid concentration. The highest amount of furfural $(\sim 10 \%)$ was found at $120{ }^{\circ} \mathrm{C}, 6 \mathrm{wt} \%$, $120 \mathrm{~min}$ and $120{ }^{\circ} \mathrm{C}, 4 \mathrm{wt} \%, 180 \mathrm{~min}$. Disregarding the $<5 \%$ impurities of the starting material, the hemicellulose conversion the highest amount of detected xylose increases to $74 \%$ and $68.5 \%$ respectively.

The calculated combined severity factors for beech wood hydrolysis are displayed in Fig. 6. The maximum xylose yields were achieved in the severity range of 2 to $3 \mathrm{CSF}$. Decreasing severity factors smaller than 2 CSFs show a decline in xylose yields. The lowest CSFs indicate that temperatures below $80^{\circ} \mathrm{C}$ are insufficient for xylose hydrolysis.

Discussion In total, beech wood xylan is possibly harder to hydrolyze than corn cob xylan at the chosen conditions. At these conditions, it shows significantly lower xylose concentrations. In addition, beech wood xylan showed poor solubility in water. Potentially unsolved xylan in the stem solution might have contributed to the decreased xylose yields. A solution for this problem could be the inclusion of optimized catalytic 
ionic acids which show increased conversion rates for oligosaccharides from hard wood [19]. Compared to the method of Sluiter et al. [12], the optimized parameters $\left(120^{\circ} \mathrm{C}, 2 \mathrm{wt} \%\right.$ acid, $120 \mathrm{~min}$ ) provide a minorly higher released xylose concentrations from beech wood xylan $(+2.3 \%)$ by reducing the degradation towards furfural $(-1.7 \%)$ at similar hemicellulose conversion rates.

\subsection{Hydrolysis optimization of C5 hydrolysate}

Results The detected monomer and corresponding concentrations of hydrolyzed C5 hydrolysate are displayed in Fig. 7. Hydrolysis of standard xylans showed highest xylose yields at low temperatures and acid concentrations within the chosen parameters. However, the screened conditions for C5 hydrolysis display no particular maximum of the released monomers. Treated C5 hydrolysate consists mainly of xylose (20 $\mathrm{g} / \mathrm{L})$ and partly glucose $(4 \mathrm{~g} / \mathrm{L})$, as well as degradation products HMF $(0.3 \mathrm{~g} / \mathrm{L})$, furfural $(1.3 \mathrm{~g} / \mathrm{L})$, and released organic acids $(3.8 \mathrm{~g} / \mathrm{L})$. The untreated $\mathrm{C} 5$ hydrolysate contains an average concentration of $3 \mathrm{~g} / \mathrm{L}$ monomeric xylose. The highest amounts of released xylose $(20.7 \mathrm{~g} / \mathrm{L})$ were detected at $110^{\circ} \mathrm{C}, 2 \mathrm{wt} \%$ sulfuric acid, and 180 -min reaction time with a furfural concentration of $1.25 \mathrm{~g} / \mathrm{L}$ (Table 8). NREL conditions $\left(120^{\circ} \mathrm{C}, 4 \mathrm{wt} \%, 60 \mathrm{~min}\right)$ resulted in $6.3 \%$ fewer released xylose $(19.4 \mathrm{~g} / \mathrm{L})$ and $21.3 \%$ higher concentrations of furfural $(1.6 \mathrm{~g} / \mathrm{L})$.

The calculated combined severity factors for C5 hydrolysate hydrolysis are displayed in Fig. 8. Xylose concentrations were found in the severity range of 1.5 to $3 \mathrm{CSF}$. No particular maximum was detected; the reaction parameters have been narrowed for a corridor of optimal hydrolysis conditions.

Standard addition of xylans to C5 hydrolysate was executed to determine the degree of conversion and effects of matrix material. Corn cob xylan was chosen as an additive agent in standard addition, because of its better comparability as stemlike biomass with $\mathrm{C} 5$ hydrolysate. The dilution row was prepared for 5.0 to $12.5 \mathrm{~g}$ in C5 hydrolysate from wheat straw. Conditions were settled at $110{ }^{\circ} \mathrm{C}, 2 \mathrm{wt} \%$ sulfuric acid, and 60-min and 90-min reaction time.

Discussion Hydrolysis at $2 \mathrm{wt} \%$ acid concentration showed the most promising results with a maximum of released xylose ranging along time and temperature axis in a broad area. This is confirmed by the severity factor which was calculated for C5 hydrolysate and plotted versus the xylose yields for all added sulfuric acid concentrations. Acid concentrations at 2 and $4 \mathrm{wt} \%$ result in a similar severity factor inside the optimum corridor, while at $6 \mathrm{wt} \%$, degradation of xylose rapidly increases.

The released xylose concentrations from corn cob xylan standards with a concentration range from 5 to $12.5 \mathrm{~g} / \mathrm{mol}$ (bottom bar), C5 hydrolysate averaged from 5 samples (top bar), and the combined solutions of both substrates (line) are displayed in Fig. 9 in triplicates including standard deviation. The recovery of monomers indicates a yield of at least $90 \%$ for each added amount of xylan to the hydrolysate. The deviation of the sum of added xylan and hydrolysate compared to the mixture is in any case lower than $2 \%$ for 60 min hydrolysis and lower than $9 \%$ for 90 min hydrolysis. This indicates that no matrix effects from either substrate inhibited the complete hydrolysis. As a result of standard addition, the transfer of the optimal hydrolysis conditions from standard xylans was achieved.

\section{Conclusion}

The aim was to find the optimal hydrolysis conditions for a maximum recovery of total xylose and the additional inclusion of the degradation products $\mathrm{HMF}$ and furfural enabling full monomeric recovery. The hydrolysis of corn cob and beech wood xylan as well as an unknown sample of a C5 hydrolysate has been analyzed by using response surface methodology based on a BoxBehnken design. Quadratic regression was used to define the effects of the variables, temperature, time, and acid concentration as well as their interaction effects on the responses of hemicellulose conversion and xylose yield. Analysis of variance developed a significant model using quadratic regression and predicted both responses with a high level of confidence. The optimized hydrolysis parameters for model xylans and unknown samples enabled the increased recovery of xylose and reduction of furfural formation. For corn cob xylan, the maximum xylose yield was found to be $77.3 \%$ $\left(100{ }^{\circ} \mathrm{C}, 2 \mathrm{wt} \%\right.$ acid, $\left.120 \mathrm{~min}\right)$ at $87.5 \%$ hemicellulose conversion, and for beech wood xylan, the maximum xylose yield was found to be $65.1 \%\left(100{ }^{\circ} \mathrm{C}, 2 \mathrm{wt} \%\right.$ acid, $120 \mathrm{~min})$ at $70.5 \%$ hemicellulose conversion. The hydrolysis parameters $\left(110{ }^{\circ} \mathrm{C}, 60 \mathrm{~min}, 2 \mathrm{wt} \% \mathrm{H}_{2} \mathrm{SO}_{4}\right)$ were found optimal for the application on liquid phase hemicellulose xylan structures. Standard addition of xylan from corn cob to C5 hydrolysate showed similar conversion rates ( $<2 \%$ deviation); no matrix effects were detected. All substrates show increased yields of released xylose and reduced furfural compared to established methods. Recovery of monomers from oligosaccharide hydrolysis was achieved at conversion rates higher than $90 \%$ including the application of correction factors for HMF and furfural.

In future works, the hydrolysis condition for hydrolysates from wheat straw and applicability of the presented method will be further investigated focusing on the conversion of wheat straw hydrolysate from steam as promising follow-up substrate. 


\section{Appendix}

\section{Acid hydrolysis thermal (oven)}

For standard hydrolysis procedure, $355 \mu \mathrm{L}$ hydrolysis mixture $\left(\mathrm{H}_{2} \mathrm{SO}_{4} 96 \%\right)$ was added to the sample $(10 \mathrm{~mL})$ in a $100-\mathrm{mL}$ glass bottle with screw cap. The bottle was incubated at 121 ${ }^{\circ} \mathrm{C}$ in an oven for $1 \mathrm{~h}$. Immediately after incubations, the bottle was cooled in an ice-water bath at $0{ }^{\circ} \mathrm{C}$ to room temperature. The solutions were transferred to $50-\mathrm{mL}$ centrifuge tubes and neutralized by adding $\mathrm{CaCO}_{3}$ until $\mathrm{pH} 7$ was adjusted. The samples were centrifuged (15 min, $4500 \mathrm{rpm}$ ), stored at $4{ }^{\circ} \mathrm{C}$ for $24 \mathrm{~h}$, again centrifuged and stored for HPLC measurement.

\section{Optimization of thermal acid hydrolysis}

Hydrolysis of oligosaccharides in the thermal oven produced undesired results. Reaction vessels suffered permanent leakage. One hundred-millimeter glass flasks cannot be sealed to fullly extend at a temperature of $140{ }^{\circ} \mathrm{C}$; all contained fluid evaporates within $180 \mathrm{~min}$, thermally decomposing the desired product saccharides. Hence, $130{ }^{\circ} \mathrm{C}$ oven temperature is the maximum temperature applicable in the presented method, though still compromised by loss of volume. Hence, thermal oven hydrolysis results are disregarded.

\section{HPLC Agilent Infinity II HPLC series details}

- Pump: product no. G7162A, Serial no. DEAC90341, made in Germany

- Auto sampler: product no. G7116A, Serial no. DEAEM05467, made in Germany

- Thermostat: product no. G7167-60101, Serial no. DEBBP07859, made in Germany

- RI detector: product no. G7111A, Serial no. DEAEZ01310, made in Germany

Table 3 Concentrations of the serial dilution standard saccharides, byproducts, and degradation products

\begin{tabular}{llllllllll}
\hline Component & $C_{1}(\mathrm{mg} / \mathrm{mL})$ & $C_{2}(\mathrm{mg} / \mathrm{mL})$ & $C_{3}(\mathrm{mg} / \mathrm{mL})$ & $C_{4}(\mathrm{mg} / \mathrm{mL})$ & $C_{5}(\mathrm{mg} / \mathrm{mL})$ & $C_{6}(\mathrm{mg} / \mathrm{mL})$ & $C_{7}(\mathrm{mg} / \mathrm{mL})$ & $C_{8}(\mathrm{mg} / \mathrm{mL})$ & $C_{9}(\mathrm{mg} / \mathrm{mL})$ \\
\hline Cellobiose & 24 & 12 & 6 & 4.8 & 2.4 & 1.2 & 0.48 & 0.24 & 0.024 \\
Glucose & 24 & 12 & 6 & 4.8 & 2.4 & 1.2 & 0.48 & 0.24 & 0.024 \\
Xylose & 24 & 12 & 6 & 4.8 & 2.4 & 1.2 & 0.48 & 0.24 & 0.024 \\
Arabinose & 24 & 12 & 6 & 4.8 & 2.4 & 1.2 & 0.48 & 0.24 & 0.024 \\
Acetic acid & 24 & 12 & 6 & 4.8 & 2.4 & 1.2 & 0.48 & 0.24 & 0.024 \\
HMF & 5 & 2.5 & 1.25 & 1 & 0.5 & 0.25 & 0.1 & 0.05 & 0.005 \\
Furfural & 5 & 2.5 & 1.25 & 1 & 0.5 & 0.25 & 0.1 & 0.05 & 0.005 \\
\hline
\end{tabular}


Table 4 Hydrolysis yields from corn cob xylan

\begin{tabular}{llllllll}
\hline $\begin{array}{l}\text { Temp } \\
\left(\mathrm{C}^{\circ}\right)\end{array}$ & $\begin{array}{l}\text { Acid } \\
(\mathrm{wt} \%)\end{array}$ & $\begin{array}{l}\text { Time } \\
(\mathrm{min})\end{array}$ & $\begin{array}{l}\text { Hemicellulose } \\
\text { conversion }(\%)\end{array}$ & $\begin{array}{l}\text { Glucose } \\
\text { yield }(\%)\end{array}$ & $\begin{array}{l}\text { Xylose } \\
\text { yield }(\%)\end{array}$ & $\begin{array}{l}\text { Arabinose } \\
\text { yield }(\%)\end{array}$ & $\begin{array}{l}\text { Furfural } \\
\text { yield }(\%)\end{array}$ \\
\hline 100 & 4 & 180 & 89.35 & 9.66 & 76.04 & 1.94 & 2.05 \\
100 & 2 & 120 & 87.48 & 5.90 & 77.42 & 1.81 & 0 \\
100 & 6 & 120 & 88.63 & 9.85 & 75.21 & 1.86 & 2.20 \\
100 & 4 & 60 & 86.27 & 6.07 & 76.27 & 1.79 & 0 \\
120 & 4 & 120 & 90.97 & 10.36 & 67.87 & 1.66 & 8.14 \\
120 & 4 & 120 & 94.38 & 10.28 & 66.50 & 1.65 & 9.03 \\
120 & 4 & 120 & 93.86 & 10.28 & 67.10 & 1.63 & 8.12 \\
120 & 6 & 180 & 90.07 & 9.72 & 54.50 & 1.46 & 15.89 \\
120 & 2 & 180 & 95.03 & 10.52 & 69.34 & 1.65 & 7.45 \\
120 & 4 & 120 & 90.51 & 10.27 & 65.80 & 1.63 & 9.23 \\
120 & 4 & 120 & 90.25 & 10.30 & 67.72 & 1.64 & 7.84 \\
120 & 6 & 60 & 92.05 & 10.22 & 68.70 & 1.66 & 6.33 \\
120 & 2 & 60 & 90.52 & 10.28 & 76.31 & 1.97 & 2.52 \\
140 & 4 & 60 & 95.45 & 9.48 & 50.31 & 1.48 & 19.67 \\
140 & 2 & 120 & 97.00 & 10.01 & 57.77 & 1.56 & 15.99 \\
140 & 6 & 120 & 81.91 & 7.36 & 18.72 & 0.86 & 33.39 \\
140 & 4 & 180 & 83.04 & 7.61 & 20.25 & 0.88 & 33.29 \\
100 & 6 & 60 & 87.49 & 7.05 & 76.06 & 1.86 & 0.97 \\
100 & 6 & 60 & 87.74 & 7.37 & 76.22 & 1.87 & 1.04 \\
100 & 6 & 120 & 88.25 & 9.34 & 75.47 & 1.87 & 1.85 \\
100 & 6 & 120 & 88.05 & 9.23 & 75.26 & 1.85 & 1.85 \\
100 & 6 & 180 & 88.83 & 10.21 & 74.27 & 1.91 & 2.79 \\
100 & 6 & 180 & 88.63 & 10.21 & 74.06 & 1.91 & 2.87 \\
100 & 4 & 180 & 89.35 & 9.66 & 76.04 & 1.94 & 2.05 \\
\hline & & & & & & & \\
\end{tabular}

Table 5 Hydrolysis yields from beech wood xylan

\begin{tabular}{llllllll}
\hline $\begin{array}{l}\text { Temp } \\
\left(\mathrm{C}^{\circ}\right)\end{array}$ & $\begin{array}{l}\text { Acid } \\
(\mathrm{wt} \%)\end{array}$ & $\begin{array}{l}\text { Time } \\
(\mathrm{min})\end{array}$ & $\begin{array}{l}\text { Hemicellulose } \\
\text { conversion }(\%)\end{array}$ & $\begin{array}{l}\text { Glucose } \\
\text { yield }(\%)\end{array}$ & $\begin{array}{l}\text { Xylose } \\
\text { yield }(\%)\end{array}$ & $\begin{array}{l}\text { Arabinose } \\
\text { yield }(\%)\end{array}$ & $\begin{array}{l}\text { Furfural } \\
\text { yield }(\%)\end{array}$ \\
\hline 80 & 4 & 180 & 29.56 & 0.37 & 29.04 & 0.52 & 0.00 \\
80 & 2 & 120 & 6.31 & 0.00 & 5.83 & 0.48 & 0.00 \\
80 & 6 & 120 & 29.30 & 0.44 & 28.80 & 0.50 & 0.00 \\
80 & 4 & 60 & 8.69 & 0.00 & 8.22 & 0.47 & 0.00 \\
100 & 4 & 120 & 63.70 & 2.33 & 63.12 & 0.58 & 0.00 \\
100 & 4 & 120 & 63.69 & 2.35 & 63.12 & 0.57 & 0.00 \\
100 & 4 & 120 & 64.14 & 2.36 & 63.56 & 0.57 & 0.00 \\
100 & 6 & 180 & 63.47 & 2.52 & 62.93 & 0.54 & 0.00 \\
100 & 2 & 180 & 62.60 & 1.81 & 62.11 & 0.49 & 0.00 \\
100 & 4 & 120 & 64.29 & 2.32 & 63.72 & 0.57 & 0.00 \\
100 & 4 & 120 & 62.22 & 1.83 & 61.74 & 0.48 & 0.00 \\
100 & 6 & 60 & 58.41 & 1.57 & 57.92 & 0.49 & 0.00 \\
100 & 2 & 60 & 33.82 & 0.53 & 33.30 & 0.52 & 0.00 \\
120 & 4 & 60 & 68.91 & 2.55 & 63.58 & 0.57 & 3.04 \\
120 & 2 & 120 & 70.48 & 2.62 & 65.13 & 0.56 & 3.06 \\
120 & 6 & 120 & 73.08 & 2.79 & 57.45 & 0.69 & 9.56 \\
120 & 4 & 180 & 74.16 & 2.90 & 58.30 & 0.71 & 9.70 \\
\hline
\end{tabular}


Table 6 Hydrolysis yields from corn cob xylan duplicate

\begin{tabular}{llllllll}
\hline $\begin{array}{l}\text { Temp } \\
\left(\mathrm{C}^{\circ}\right)\end{array}$ & $\begin{array}{l}\text { Acid } \\
(\mathrm{wt} \%)\end{array}$ & $\begin{array}{l}\text { Time } \\
(\mathrm{min})\end{array}$ & $\begin{array}{l}\text { Hemicellulose } \\
\text { conversion }(\%)\end{array}$ & $\begin{array}{l}\text { Glucose } \\
\text { yield }(\%)\end{array}$ & $\begin{array}{l}\text { Xylose } \\
\text { yield }(\%)\end{array}$ & $\begin{array}{l}\text { Arabinose } \\
\text { yield }(\%)\end{array}$ & $\begin{array}{l}\text { Furfural } \\
\text { yield }(\%)\end{array}$ \\
\hline 100 & 4 & 180 & 84.91 & 8.51 & 72.34 & 1.47 & 1.78 \\
100 & 2 & 120 & 83.25 & 4.88 & 73.51 & 1.52 & 0.00 \\
100 & 6 & 120 & 89.04 & 8.34 & 70.76 & 1.47 & 2.34 \\
100 & 4 & 60 & 82.03 & 5.12 & 72.55 & 1.51 & 0.00 \\
110 & 4 & 120 & 90.31 & 10.14 & 71.77 & 1.63 & 3.27 \\
110 & 4 & 120 & 88.52 & 10.15 & 71.51 & 1.62 & 3.63 \\
110 & 4 & 120 & 86.65 & 10.15 & 71.57 & 1.63 & 3.30 \\
110 & 6 & 180 & 87.84 & 10.07 & 66.39 & 1.57 & 7.24 \\
110 & 2 & 180 & 87.50 & 10.07 & 72.85 & 1.64 & 3.03 \\
110 & 4 & 120 & 87.64 & 10.26 & 72.04 & 1.68 & 3.41 \\
110 & 4 & 120 & 87.74 & 10.16 & 71.67 & 1.64 & 3.30 \\
110 & 6 & 60 & 86.95 & 10.00 & 72.37 & 1.64 & 2.97 \\
110 & 2 & 60 & 83.46 & 6.10 & 73.83 & 1.53 & 0.00 \\
120 & 4 & 60 & 87.78 & 10.19 & 70.24 & 1.66 & 4.59 \\
120 & 2 & 120 & 87.70 & 10.18 & 70.75 & 1.65 & 4.53 \\
120 & 6 & 120 & 91.01 & 9.82 & 60.61 & 1.54 & 11.25 \\
120 & 4 & 180 & 90.05 & 9.90 & 61.09 & 1.54 & 11.62 \\
\hline
\end{tabular}

Table 7 Hydrolysis yields from beech wood xylan duplicate

\begin{tabular}{llllllll}
\hline $\begin{array}{l}\text { Temp } \\
\left(\mathrm{C}^{\circ}\right)\end{array}$ & $\begin{array}{l}\text { Acid } \\
(\mathrm{wt} \%)\end{array}$ & $\begin{array}{l}\text { Time } \\
(\mathrm{min})\end{array}$ & $\begin{array}{l}\text { Hemicellulose } \\
\text { conversion }(\%)\end{array}$ & $\begin{array}{l}\text { Glucose } \\
\text { yield }(\%)\end{array}$ & $\begin{array}{l}\text { Xylose } \\
\text { yield }(\%)\end{array}$ & $\begin{array}{l}\text { Arabinose } \\
\text { yield }(\%)\end{array}$ & $\begin{array}{l}\text { Furfural } \\
\text { yield }(\%)\end{array}$ \\
\hline 100 & 4 & 180 & 65.59 & 2.19 & 59.16 & 0.29 & 0.00 \\
100 & 2 & 120 & 55.73 & 1.13 & 55.42 & 0.31 & 0.00 \\
100 & 6 & 120 & 60.81 & 2.03 & 60.52 & 0.30 & 0.00 \\
100 & 4 & 60 & 53.82 & 1.10 & 53.51 & 0.31 & 0.00 \\
110 & 4 & 120 & 66.29 & 2.29 & 61.70 & 0.30 & 0.00 \\
110 & 4 & 120 & 65.94 & 2.32 & 61.70 & 0.30 & 0.00 \\
110 & 4 & 120 & 66.17 & 2.31 & 61.50 & 0.31 & 0.00 \\
110 & 6 & 180 & 67.51 & 2.62 & 58.12 & 0.31 & 0.00 \\
110 & 2 & 180 & 66.81 & 2.44 & 62.77 & 0.30 & 0.00 \\
110 & 4 & 120 & 65.55 & 2.29 & 60.69 & 0.30 & 0.00 \\
110 & 4 & 120 & 66.72 & 2.62 & 57.91 & 0.31 & 0.00 \\
110 & 6 & 60 & 66.97 & 2.87 & 62.78 & 0.31 & 0.00 \\
110 & 2 & 60 & 61.42 & 1.70 & 61.12 & 0.31 & 0.00 \\
120 & 4 & 60 & 67.91 & 2.94 & 62.05 & 0.31 & 0.00 \\
120 & 2 & 120 & 68.32 & 2.87 & 62.69 & 0.32 & 0.00 \\
120 & 6 & 120 & 70.74 & 2.30 & 53.70 & 0.35 & 0.00 \\
120 & 4 & 180 & 71.29 & 2.39 & 55.71 & 0.34 & 0.00 \\
\hline
\end{tabular}


Table 8 Hydrolysis C5

hydrolysate

\begin{tabular}{llllllll}
\hline $\begin{array}{l}\text { Temp } \\
\left(\mathrm{C}^{\circ}\right)\end{array}$ & $\begin{array}{l}\text { Acid } \\
(\mathrm{wt} \%)\end{array}$ & $\begin{array}{l}\text { Time } \\
(\mathrm{min})\end{array}$ & $\begin{array}{l}\text { Glucose } \\
\text { conc }[\mathrm{g} / \mathrm{L}]\end{array}$ & $\begin{array}{l}\text { Xylose } \\
\text { conc }[\mathrm{g} / \mathrm{L}]\end{array}$ & $\begin{array}{l}\text { Arabinose } \\
\text { conc }[\mathrm{g} / \mathrm{L}]\end{array}$ & $\begin{array}{l}\text { Furfural } \\
\text { conc }[\mathrm{g} / \mathrm{L}]\end{array}$ & $\begin{array}{l}\text { HMF conc } \\
{[\mathrm{g} / \mathrm{L}]}\end{array}$ \\
\hline 100 & 4 & 180 & 3.68 & 20.41 & 2.11 & 1.22 & 0.27 \\
100 & 2 & 120 & 2.06 & 19.94 & 2.00 & 1.00 & 0.17 \\
100 & 6 & 120 & 3.66 & 20.13 & 2.07 & 1.22 & 0.26 \\
100 & 4 & 60 & 2.19 & 19.46 & 1.97 & 1.00 & 0.17 \\
110 & 4 & 120 & 4.04 & 19.77 & 2.06 & 1.40 & 0.32 \\
110 & 4 & 120 & 4.02 & 19.63 & 2.06 & 1.43 & 0.32 \\
110 & 4 & 120 & 4.02 & 19.81 & 2.06 & 1.40 & 0.32 \\
110 & 6 & 180 & 3.96 & 17.07 & 1.77 & 1.82 & 0.19 \\
110 & 2 & 180 & 3.66 & 20.78 & 2.03 & 1.25 & 0.29 \\
110 & 4 & 120 & 3.99 & 19.82 & 2.05 & 1.37 & 0.31 \\
110 & 4 & 120 & 4.03 & 19.71 & 2.06 & 1.41 & 0.32 \\
110 & 6 & 60 & 3.57 & 19.74 & 2.00 & 1.27 & 0.27 \\
110 & 2 & 60 & 2.20 & 20.00 & 1.97 & 1.03 & 0.18 \\
120 & 4 & 60 & 4.06 & 19.42 & 2.00 & 1.59 & 0.35 \\
120 & 2 & 120 & 4.69 & 20.28 & 2.02 & 1.58 & 0.38 \\
120 & 6 & 120 & 4.53 & 17.60 & 1.73 & 2.32 & 0.14 \\
120 & 4 & 180 & 3.96 & 17.45 & 1.75 & 2.33 & 0.15 \\
120 & 0 & 180 & 0.62 & 4.03 & 0.91 & 0.82 & 0.08 \\
Untreated & sample & & 0.50 & 3.47 & 0.82 & 2.02 & 0.75 \\
\hline
\end{tabular}

Table 9 ANOVA (analysis of variance)

\begin{tabular}{llllllll}
\hline Substrate & Source & Sum of squares & df & Mean square & $\begin{array}{l}F- \\
\text { value }\end{array}$ & $p$-value prob $>F$ & Significance \\
\hline Xylose CCX & Model & 75.14 & 9 & 8.35 & 650.89 & $<0.0001$ & Significant \\
Furfural CCX & Model & 10.53 & 9 & 1.17 & 226.47 & $<0.0001$ & Significant \\
Xylose BWX & Model & 82.51 & 9 & 9.17 & 21.02 & 0.0003 & Significant \\
Furfural BWX & Model & 0.82 & 9 & 0.091 & 11.18 & 0.0022 & Significant \\
Xylose C5 & Model & 17.71 & 9 & 1.97 & 44.15 & $<0.0001$ & Significant \\
Furfural C5 & Model & 2.42 & 9 & 0.27 & 33.36 & $<0.0001$ & Significant \\
\hline
\end{tabular}

Xylose CCX = concentration of released xylose from corn cob xylan; furfural CCX = concentration of converted furfural from corn cob xylan; xylose $\mathrm{BWX}=$ concentration of released xylose from beech wood xylan; furfural BWX = concentration of converted furfural from beech wood xylan; xylose $\mathrm{C} 5=$ concentration of released xylose from liquid hot water wheat straw hydrolysate; furfural $\mathrm{C} 5=$ concentration of released and converted furfural from liquid hot water wheat straw hydrolysate 
Supplementary Information The online version contains supplementary material available at https://doi.org/10.1007/s13399-021-01429-6 .

Code availability None used

Funding Open Access funding enabled and organized by Projekt DEAL. The ELBE-NH research project was supported via $t$ Project Management Jülich, commissioned by the Federal Ministry of Education and Research.

Data availability All data will be provided transparently.

\section{Declarations}

Conflict of interest The authors declare no competing interests.

Open Access This article is licensed under a Creative Commons Attribution 4.0 International License, which permits use, sharing, adaptation, distribution and reproduction in any medium or format, as long as you give appropriate credit to the original author(s) and the source, provide a link to the Creative Commons licence, and indicate if changes were made. The images or other third party material in this article are included in the article's Creative Commons licence, unless indicated otherwise in a credit line to the material. If material is not included in the article's Creative Commons licence and your intended use is not permitted by statutory regulation or exceeds the permitted use, you will need to obtain permission directly from the copyright holder. To view a copy of this licence, visit http://creativecommons.org/licenses/by/4.0/.

\section{References}

1. Dusselier M, Mascal M, Sels BF (2014) Top chemical opportunities from carbohydrate biomass: a chemist's view of the biorefinery. In: Nicholas KM (ed) Selective catalysis for renewable feedstocks and chemicals. Springer International Publishing, Cham, pp 1-40

2. Fagerson IS (1969) Thermal degradation of carbohydrates; a review. J Agric Food Chem 17:747-750

3. Weingarten R, Cho J, Xing R, Conner WC, Huber GW (2012) Kinetics and reaction engineering of levulinic acid production from aqueous glucose solutions. ChemSusChem 5(7):1280-1290. https://doi.org/10.1002/cssc.201100717

4. Tsai Y-D (2012) Dilute acid hydrolysis of oligomers in hydrothermal pretreatment hydrolyzate into monomers with high yields. Masters Thesis, University of California Riverside

5. Lamp A, Kaltschmitt M, Lüdtke O (2018) Improved HPLC-method for estimation and correction of amino acid losses during hydrolysis of unknown samples. Anal Biochem 543:140-145. https://doi.org/ 10.1016/j.ab.2017.12.009

6. Peter B, Thaler H, Täufel K (1933) Zur Analytik der Pentosane. Mitteilung aus dem Uliversitätsinstitut und der Deutschen Forschungsanstalt für Lebensmittelchemie in München 1933(66): $143-57$.
7. Rennie EA, Scheller HV (2014) Xylan biosynthesis. Curr Opin Biotechnol 26:100-107. https://doi.org/10.1016/j.copbio.2013.11. 013

8. Melim Miguel AS, Souza T, EVd CF, Paulo Lobo BW, Maria G (2013) Enzymes in bakery: current and future trends. In: Muzzalupo I (ed) Food Industry. InTech, Princeton

9. van Zandvoort I, Wang Y, Rasrendra CB, van Eck ERH, Bruijnincx PCA, Heeres HJ et al (2013) Formation, molecular structure, and morphology of humins in biomass conversion: influence of feedstock and processing conditions. ChemSusChem 6(9):1745-1758. https://doi.org/10.1002/cssc.201300332

10. Lavarack BP, Griffin GJ, Rodman D (2002) The acid hydrolysis of sugarcane bagasse hemicellulose to produce xylose, arabinose, glucose and other products. Biomass Bioenergy 23(5):367-380. https://doi.org/10.1016/S0961-9534(02)00066-1

11. Tungland BC (2003) Fructooligosaccharides and Other Fructans: Structures and occurrence, production, regulatory aspects, food applications, and nutritional health significance. In: Eggleston G, Cote GL (eds) Oligosaccharides in food and agriculture. American Chemical Society, Washington, DC, pp 135-152

12. Sluiter A, Hames B, Ruiz R, Scarlata C, Sluiter J, Templeton D (2008) Determination of sugars, byproducts, and degradation products in liquid fraction process samples: laboratory analytical procedure (LAP); Issue Date: 12/08/2006. Technical Report NREL/TP510-42623 January 2008

13. Huynh B-L, Palmer L, Mather DE, Wallwork H, Graham RD, Welch RM, Stangoulis JCR (2008) Genotypic variation in wheat grain fructan content revealed by a simplified HPLC method. J Cereal Sci 48(2):369-378. https://doi.org/10.1016/j.jcs.2007.10. 004

14. Verspreet J, Pollet A, Cuyvers S, Vergauwen R, van den Ende W, Delcour JA, Courtin CM (2012) A simple and accurate method for determining wheat grain fructan content and average degree of polymerization. J Agric Food Chem 60(9):2102-2107. https://doi.org/ $10.1021 / \mathrm{jf} 204774 \mathrm{n}$

15. Thomann R (1982) Eine günstige Bestimmungsmethode für lösliche Pentosane. Die Nahrung 26(6):515-518

16. Reynolds W, Singer H, Schug S, Smirnova I (2015) Hydrothermal flow-through treatment of wheat-straw: detailed characterization of fixed-bed properties and axial dispersion. Chem Eng J 281:696703. https://doi.org/10.1016/j.cej.2015.06.117

17. Chen W-H, Ye S-C, Sheen H-K (2012) Hydrolysis characteristics of sugarcane bagasse pretreated by dilute acid solution in a microwave irradiation environment. Appl Energy 93:237-244. https:// doi.org/10.1016/j.apenergy.2011.12.014

18. Anderson M, Whitcomb P (2020) Design Expert 9.0. Minneapolis, Minnesota, USA: Stat-Ease

19. Matsagar BM, Dhepe PL (2015) Brönsted acidic ionic liquidcatalyzed conversion of hemicellulose into sugars. Catal Sci Technol 5(1):531-539. https://doi.org/10.1039/C4CY01047G

Publisher's Note Springer Nature remains neutral with regard to jurisdictional claims in published maps and institutional affiliations. 